Norsk sosiologforenings hederspris 2005 til Nils Christie

Publisert i Sosiologisk Tidsskrift 2005; 13(1):83-91

Gunn Elisabeth Birkelund, Universitetet i Oslo

g.e.birkelund@sosiologi.uio.no

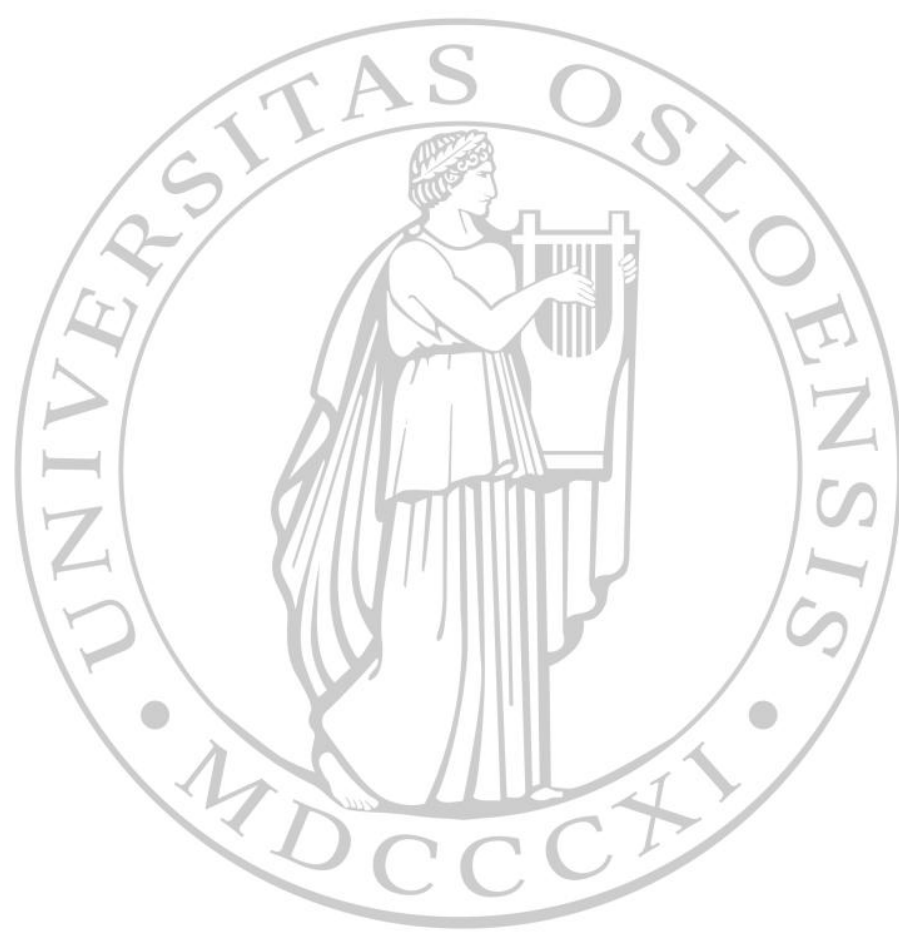

Department of Sociology and Human Geography University of Oslo

P.O.Box 1096 Blindern

N-0317 OSLO Norway

Telephone: $\quad+4722855257$

Fax:

$+4722855253$

Internet: http://www.iss.uio.no 


\section{NORSK SOSIOLOGFORENINGS HEDERSPRIS 2005 TIL NILS CHRISTIE}

Gunn Elisabeth Birkelund

g.e.birkelund@sosiologi.uio.no

Sosiologforeningens hederspris skal gå til personer som på en fortjenestefull måte har

preget norsk sosiologi eller til norske sosiologer som har markert seg internasjonalt.

Hedersprisen er tidligere blitt tildelt Arvid Brodersen og Sverre Holm (1996), Arne Næss og Hans Skjervheim (1997), Ørjar Øyen og Yngvar Løchen (1998), Natalie Rogoff Ramsøy og Harriet Holter (1999), Ottar Brox (2000), Johan Galtung (2001), Dag Østerberg (2002), Tore Lindbekk (2003) og Fredrik Engelstad (2004).

I år har vi gleden å gi hedersprisen til professor i kriminologi ved Universitetet i Oslo: Nils Christie.

Nils Christie er født 24.02 1928. Han tok magistergraden i sosiologi i $1952 \mathrm{og}$ ble Dr. philos. i 1960. Han har en svært omfattende faglig produksjon (publikasjonsliste på 28 sider). Svært mange av bøkene er oversatt til en rekke språk. Det sier seg selv at det ikke er mulig å gi en grundig gjennomgang av en så omfattende publikasjonsliste, derfor vil det bare være et utdrag som presenteres her. Men skulle jeg prøve meg på en sammenfatning, vil jeg si at forfatterskapet hans kretser rundt tre tema: Sosialt avvik, sosial kontroll og sosial interaksjon. Disse tre temaene henger nøye sammen, slik at forfatterskapet preges av en stringens i argumentasjonen som jeg neppe klarer å få godt nok frem i denne presentasjonen. La det derfor bare være nevnt, som inspirasjon til lesning av hans publikasjoner.

Nils Christie drøfter sosialt avvik i forhold til normalitet og hva samfunnet definerer som avvik. Stikkord her: Vi er alle lovbrytere. Han er opptatt av sosial kontroll og å forstå rettsvesenet i et systemperspektiv. Og han peker på sammenhengen mellom avvik og sosial integrasjon i samfunnet. Spissformulert: Straff bidrar ikke konstruktivt til sosial integrasjon. 


\section{Ad sosialt avvik}

\section{Fangevoktere}

Magisteravhandlingen fra 1952 har tittelen Fangevoktere $i$ konsentrasjonsleire. En sosiologisk undersøkelse av norske fangevoktere $i$ "serberleirene» $i$ Nord-Norge $i$ 1942-43.

Sommeren 1942 begynte tyskerne å sende Jugoslaviske fanger, for det meste serbere, til Norge for å internere dem i fangeleire i Nord-Norge. Både tyskere og nordmenn ble rekruttert som fangevoktere. Det ble etablert fem leire, som ble kalt serberleirene, i Nord-Norge. Leirene var preget av forferdelige forhold: sult, kulde, tvangsarbeid, mishandling og dødsfall, og kan sammenlignes «med den dårligste del av konsentrasjonsleirene i Tyskland» (s. 60). Av de første «sendinger» sommeren 1943 på i overkant av 2500 serbere, var 1700 (omtrent 70 \%) omkommet etter det første året.

Etter krigen ble også nordmenn dømt for mishandling og drap av fangene i disse leirene. Hva kan forklare at vanlige mennesker blir drapsmenn og begår alvorlige overgrep mot andre mennesker? Hva skiller overgriperne fra de øvrige? Nils Christie prøver å finne svar på dette ved å gå empirisk grundig til verks. Bare det å skaffe oversikt over hvor mange nordmenn som hadde vært fangevoktere i disse leirene var et detektivarbeid. Nils Christie kommer frem til at det var 363 nordmenn som var fangevoktere i perioden 1942-43. Av disse ble 43 dømt for mishandling eller drap etter krigen var over. Han oppsøker 30 av de 43 norske vokterne som ble dømt etter krigen i fengslene og intervjuer dem. Og han intervjuer 33 av de øvrige fangevokterne, som ikke ble dømt for mishandling eller drap, for å kunne bruke dem som 'kontrastgruppe' til de dømte. Han analyserer alle dokumenter fra alle rettssakene mot fangevokterne etter krigen og dette materialet (som er ganske omfattende) sammen med intervjuene utgjør hovedmaterialet for avhandlingen.

Hva var resultatene av alle disse analysene? Kort fortalt fant Nils Christie ut at det var mindre som skilte mishandlerne/drapsmennene fra de øvrige fangevokterne enn han hadde antatt på forhånd. Det var ikke mulig å skille mishandlerne/drapsmennene fra de øvrige fangevokterne mht utdanning eller yrke, evt tidligere kriminalitet, eller hvordan de skåret på en psykologisk autoritetstest: «Derimot atskilte de seg ved at de var yngre, (...) og ... ved å ha en annen innstilling til serberne.» (s 168)

De som var dømt for drap eller mishandling hadde hatt mindre kontakt med serberne på det personlige plan enn de øvrige fangevokterne. Dette kan sannsynligvis forklare hvorfor de betraktet serberne som en gruppe, ikke som enkeltindivider, med mindreverdige egenskaper. De mente også at serberne var farlige. Dette, skriver Nils Christie, er sannsynligvis holdninger som gjorde det 
mulig for fangevokterne å omgå sitt eget normsystem om at man skal ikke mishandle og drepe andre mennesker. I denne situasjonen kunne og gjorde de det.

Nils Christie drøfter den sosiale organisering i leirene og andre faktorer som kan bidra til å skape situasjoner hvor mennesker begår overgrep. Han trekker frem vaktenes fortellinger om lange vakttjenester, om et strengt autoritetshierarki, utstrakt bruk av trusler og differensiering etter nasjonalitet. Han trekker frem levekårene, både for vaktene og fangene i leirene, og geografisk isolasjon og konkluderer avhandlingen med å legge vekt på hvordan den sosiale situasjonen disse fangevokterne var $i$ kan bidra til å forklare at noen av dem ble drapsmenn:

"Vakter som mishandler og dreper $i$ konsentrasjonsleire er yngre og har mindre erfaring (....) enn de som i samme situasjon ikke mishandler og dreper. (.....) de kan ha samme normer, de kan ha samme meninger, de kunne ha blitt som andre unge. Og viktigst, de andre kunne blitt som dem, hvis de var havnet $i$ samme situasjon og utsatt for det samme press. (...) Målet må være å hindre at samme situasjon oppstår.» (s 169).

Avhandlingen ble møtt med taushet i offentligheten, noe som kan antydet skyldes at nordmenn så raskt etter krigen ikke var lydhøre overfor meldingen om at bødlene ikke var udyr. Først 20 år senere, i 1972, ble avhandlingen utgitt som Pax bok (etter initiativ fra Nils Petter Gleditsch, som takkes i forordet fra 1971). Dette tema er dessverre viktig også i dag (jfr amerikanske soldaters mishandlinger i Irak).

\section{Unge norske lovovertredere}

Dr. Philos.-avhandlingen Unge norske lovovertredere, Universitetsforlaget 1960, er en grundig statistisk analyse basert på militærregistre av hele årskullet unge menn født i 1933.

Nils Christie fikk tak i informasjon om hvem av dem som var registrert som lovovertredere, og sammenligner disse med årsklassen forøvrig for å finne evt forskjeller og likheter mellom de som ble lovovertredere og de som ikke blir det. Nils Christie sammenfatter sine funn slik:

"Registrerte mannlige lovovertredere utgjør ca $5 \%$ av årsklassen. Lovbruddet dreier seg $i$ det alt vesentlige om vinningsforbrytelser. Tilbakefall skjer hyppigere enn tidligere antatt, (...). Sammenlignes lovovertrederne med deres jevnaldrende kommer enkelte forskjeller tydelig fram. I markert grad har de registrerte lovovertrederne en mer bymessig preget bakgrunn enn årsklassens øvrige medlemmer. De har videre noe dårligere boligforhold, noe større tendens til å komme fra ufullstendige eller små 
familieenheter, større tendens til å komme fra familier med lav sosial rang og til selv a ha et yrke med lav sosial rang og med adgang til å fore en omflakkende tilvxrelse, og endelig: de har en utpreget tendens til å ha et utdannelsesmessig og/eller evnemessig handikap.

Men denne fremhevning av forskjeller representerer bare én side av saken. Likeså viktig er det kanskje å fremheve den annen side: På mange områder er våre resultater preget av storre eller mindre likheter mellom registrerte lovovertredere og årsklassen for ovrig. Både ved boligforhold, familieforhold, helseforhold og personlighetsforhold er det likhetene som dominerer bildet.» (263-264).

Her vise Nils Christie sin evne til å holde to tanker i hodet samtidig. Selv om analysene viser at det er statistisk signifikante forskjeller mellom to grupper, behøver ikke dette bety at tolkningen kun skal baseres på disse forskjellene. Snarere kan det være grunn til å føye til at hovedbildet er at på tross av visse forskjeller, er det likhetene som er mest slående. Poenget med tolkning er at den må ses i forhold til hva man forventer å finne. Og når forventningene var at det ville være store forskjeller mellom disse to gruppene, så valgte Nils Christie å vektlegge at disse forskjellene ikke var så store som man hadde trodd.

Artikkelen "A Study of Self-reported Crime», skrevet av Nils Christie, Johs. Andenæs og Sigurd Skirbekk (Scandinavian Studies in Criminology, 1965) viste dessuten at det er relativt små sosiale forskjeller i folks selvrapporterte lovbrudd. Dermed står vi ved Nils Christies konklusjon mht sosialt avvik: Vi er alle lovbrytere - selv om de fleste av oss er det i liten skala. Dette hovedbudskapet har vært med på å forme den offentlige opinion og debatt om kriminalitet. På 1960-tallet var samfunnet preget av svart/hvitt-tenkning om 'forbrytere' versus oss andre, så dette var helt nye tanker. Men hvis vi alle er lovbrytere, hvorfor blir noen av oss definert som avvikere og andre ikke? For å forstå dette, må vi se avvik i forhold til et system som skiller 'avvikerne' fra de 'normale' i et samfunn. Da er vi over på Nils Christies andre tema: Sosial kontroll.

\section{Ad sosial kontroll}

I et arbeid fra slutten av 1960-tallet peker Christie på at kriminologi tidligere besto av «the study of criminals in splendid isolation from the formal system of control.» Dette betydde at man bare la vekt på sluttresultatet av det offentlige kontrollsystemet, nemlig hvem som ble definert som kriminelle, uten å problematisere selve kontrollsystemet. Men, skriver han: "As criminology matures, studies of social control become a topic of paramount importance.» (Editor's preface, Scand. Studies of Criminology, 1968, vol. 2, temanummer om «Aspects of Social Control in Welfare States»). 


\section{Tvangsarbeid}

Allerede I 1960 publiserte Nils Christie en bok om sosial kontroll: Tvangsarbeid og alkohol, også denne utgitt på Universitetsforlaget. Her analyseres tvangsarbeid (som også omtales i offentligheten som arbeidsterapi) i et kritisk lys. Lov om losgjangeri, Betleri og Drukkenskab fra mai 1900 angir betingelsene for tvangsarbeid. Nils Christie peker på at tvangsarbeid ikke fungerer etter hensikten, og løsgjengerloven ble da også opphevet i 1970.

Boken inneholder blant annet en kritisk analyse av profesjonenes rolle i rettsapparatet. Dette temaet er Nils Christie er kommet tilbake til en rekke ganger i sitt forfatterskap; hvordan norsk lovgivning, særlig strafferett, innebærer at enkelte profesjoner (særlig leger og jurister) tillegges arbeidsoppgaver som ligger utenfor deres kompetanse. Rettspsykiaterne har for stor makt i dag, og bør heller skrive små noveller (se Christies innlegg i dette nummer av Sosiologisk tidsskrift).

\section{Den skjeve pyramide}

I boken Hvor tett et samfunn (1982) har Nils Christie inkludert et omfattende kapittel som dokumenterer tidligere funn om at vi alle er lovbrytere, men som også viser at det slett ikke er lik sannsynlighet for at alle blir definert som lovovertredere. Han gjengir den 'skjeve pyramide', som viser at "antall registreringer for lovbrudd øker meget sterkt med synkende sosialklasse.» Mao - alle begår lovbrudd, men rettsapparatet er selektivt mht hvem som registreres og hvilke typer lovbrudd som etterforskes.

Dette ståstedet er senere utfordret av bla Willy Pedersen (1992), som synes fagmiljøet på kriminologi i altfor liten grad har konsentrert seg om å identifisere de som begår alvorlige lovbrudd og som i hht data fra Ungforsk-undersøkelsene er en liten og utsatt gruppe ungdom. Når Nils Christie og andre definerer oss alle som lovovertredere gjør de disse ungdommene en bjørnetjeneste ved ikke å identifisere hvem de er slik at de kan hjelpes til et bedre liv, skriver Willy Pedersen.

Her svarer Nils Christie (1992) at det er korrekt at kriminologene har lagt stor vekt på å få ut i offentligheten en forståelse av verden ikke er svart/hvitt mht rett og galt, men at vi alle kan være lovbrytere, og til dels også er dette. Identifikasjon av de som begår alvorlige lovbrudd vil også synliggjøre dem som en avviksgruppe. Og det er fremdeles viktig å problematisere systemets rolle mht identifikasjon av hva som regnes som viktige lovbrudd, hva som anmeldes, etterforskes, evt henlegges, og hva som fører til siktelse. Satt på spissen: Hvitsnippforbrytelser gis mindre prioritet enn tyveri, vold og annet. Alt dette må også tas med, ellers kan forskningen bidra til økt og ikke mindre stigmatisering av lovbryterne.

Altså: Forskningen må ha et systemperspektiv i tillegg til et individperspektiv. I dag skulle tiden være moden for å få frem begge meldingene. 


\section{Ad sosial integrasjon}

Ut i fra en målsetting om å integrere mennesker bedre i samfunnet kan det være lite klokt å isolere dem i lukkede institusjoner. Dette vil også gjelde for de som har begått kriminelle handlinger. Det er altså en sammenheng mellom sosial integrasjon og straff.

\section{Straff}

Nils Christies kanskje viktigste kriminalpolitiske arbeider drøfter straffens vesen. Her anvender han begrep som pine, jfr boken som på norsk har fått tittelen Pinens begrensing (1982) (på engelsk: Limits to Pain). Straff dreier seg om påføring av pine. Spørsmålene som reiser seg når en drøfter straffeteori og -praksis er blant annet hvor mye pine og på hvilken måte. Tidligere ble man fysisk avstraffet; i moderne velferdsstater i dag straffes man ved frihetsberøvelse og isolasjon, først og fremst. Nils Christies ståsted spissformulert: Straff fungerer ikke, verken individual- eller allmennpreventivt.

\section{Gulag i Vesten?}

I boken Kriminalitetskontroll som industri. Mot GULAG, vestlig type? (som første gang ble utgitt i 1993) viser Nils Christie empirisk hvor stor variasjon det er mellom land i Europa (Øst- og Vest-Europa), Nord-, Mellom og Sør-Amerika mht andelen av befolkningen som sitter i fengsel. Som kjent kommer Gulagbegrepet fra Russland (egentlig Sovjetunionen), og Russland ligger fremdeles svært høyt på statistikken over antall fanger pr 100000 innbyggere. Men særlig i USA har det vært en galopperende utvikling: I løpet av 1990-tallet har USA $ø \mathrm{kt}$ fra i underkant av 500 fanger per 100000 innbyggere (et ufattelig høyt tall som bare Russland kan konkurrere med) - til over 700 fanger pr 100000 innbyggere i 2000.

Nils Christie drøfter om fengselsvesenet er blitt en industri også i Vesten, og trekker trådene tilbake til leirene under 2. verdenskrig. Boken preges, synes jeg, av en mer pessimistisk tone enn vi finner i hans tidligere arbeid. Vi har beveget oss, skriver Nils Christie, fra en forståelse av utryddelsesleirene som produkter av abnorme mennesker, via et annet stadium hvor vi så på dette som et produkt av abnorme system (her faller hans egen magisteravhandling inn, noe han selv påpeker), til et nytt stadium hvor vi - med Bauman - ser utryddelsen som et produkt av vår egen samfunnsform.

Mot dette kan jeg bare bidra med mine ord, skriver Nils Christie, og håpe at de får betydning slik at denne utvikling ikke oppfattes om en nødvendighet (s. 175). Og hans eget alternativ er å påpeke at straff ikke virker. Det eneste vi oppnår ved fengselsstraff er å øke sannsynligheten for tilbakefall/mer kriminalitet. Derfor bør 
lovovertrederne raskest mulig komme tilbake i samfunnet og ikke isoleres i pinefulle straffeanstalter (les: fengsler) som berøver dem deres frihet og verdighet.

Crime Control as Industry, som opprinnelig ble skrevet på engelsk, er oversatt til tretten språk. I det britiske tidsskriftet Sociology, skriver Zygmunt Bauman flg om denne boken: "I regret I was not acquainted with Christie's findings at the time I wrote Modernity and the Holocaust.» (Bauman, sitert på baksiden av Christies bok i engelsk utgave). Og I tidsskriftet Criminology omtales boken som "another outstanding contribution from one of the world's leading criminologists.» (W. Chambliss, sitert på baksiden av Christies bok i engelsk utgave).

\section{Annet}

Christie har skrevet en rekke andre bøker og artikler. Noen av disse bøkene har bidratt til den offentlige debatt. Blant de mest kjente er Hvis skolen ikke fantes (1971). Her kritiserer Nils Christie skolen for å skape tapere. Nils Christie har også skrevet mye om ulike former for rusmidler, fra alkoholbruk blant ungdom i Oslo på 1960-tallet, til Den gode fiende. Narkotikapolitikk i Norden (1985). Her er han opptatt av at narkotikapolitikken er feilslått fordi den lager stadig nye tapere i samfunnet, som straffes med fengselsstraffer som ikke står i noe forhold til alvorligheten av rusmisbruket. Boken Bortenfor anstalt og ensomhet. Om landsbyer for usedvanlige mennesker (1989) handler om bofellesskap blant psykisk utviklingshemmede og retten til å leve et liv på egne premisser.

Selv om disse bøkene handler om ulike tema, kretser de alle rundt felles problemstillinger knyttet til sosialt avvik, sosial kontroll og sosial integrasjon. Vi bør også nevne at Nils Christie har samarbeidet med H. O. Christophersen (hovedredaktør) og K. Petersen om redigeringen av Eilert Sundts verker $i$ utvalg, som ble utgitt på Gyldendal norsk forlag på 1970-tallet i en serie på 11 bind.

\section{Hedersprisen til Nils Chrisite}

Nils Christie har stått helt sentralt i utviklingen av faget kriminologi i Norge. I hans arbeider kan man lese tydelig påvirkning fra både sosialpsykologi, sosialiserings- og bytteteori og strukturfunksjonalistiske resonnementer. Han refererer kontinuerlig til innflytelsen fra sosiologiens klassikere og mer moderne bidrag. Slik sett flyter de to fagene jevnt og harmonisk side om side i hans arbeid.

Nils Christie har også poengtert at skandinavisk og kanskje særlig norsk kriminologi er nært beslektet med sosiologi, i motsetning til hva som er tilfelle mange andre steder (hvor det for eksempel ofte kan væere psykologi som er nærmere). Dette betyr at skandinavisk kriminologi har vært preget av en interesse ikke bare for lovovertrederne og deres karakteristika, men vel så mye av 
interesse for systemene, dvs. straffesystemet, rettsapparatet, og allmenne moral- og rettferdighetsoppfatninger, osv. Dette er et felt som selvsagt bygger på bl.a. Auberts arbeid, men som Nils Christie har videreutviklet.

\section{Speilet}

Innflytelsen fra sosiologi ser vi også tydelig i Nils Christies definisjonen av kriminologi: «... kriminologien ikke bare er til for å kaste lys på avvik og sosial kontroll, men også for å kaste lys tilbake på det vanlige. (...) Vi får et klarere lys på det vanlige i Norge ved å se på det uvanlige, eller den del det står strid om.» (1997: 96).

Gjennom studier av avvikere holder Nils Christie opp et speil for oss (og refererer til Cooley): Fortell meg hva du ser, og jeg skal si deg hvem du er. Overført: fortell meg hvem du definerer som avvikere og hvordan du behandler dem og jeg skal fortelle deg hvem du er. Mao: studier av avvik er også studier av normalitet.

\section{Släpp fångarne loss!}

Det går en rød tråd gjennom hele Nils Christies virke: han skriver utifra et grunnleggende humanistisk ståsted: Alle mennesker har en egenverdi. Derfor blir studier av sosial avvik også studier av normalitet.

Faglig ser vi et tydelig systemperspektiv: mennesker preges av de sosiale omgivelsene de inngår i. Derfor blir studier av sosial kontroll også studier av rettsapparatet og straffepolitikken.

Og politisk ser vi et tydelig reformperspektiv: skal vi komme noen vei med sosial integrasjon av avvikerne må vi bygge opp systemene slik at de fungerer rasjonelt og bidrar til å styrke det gode og svekke det onde.

Det er hevet over enhver tvil at Nils Christie er og har vaert en aktør med betydelig troverdighet i den fag-politiske debatten om forbrytelse og straff. Han har vært medlem av en rekke offentlige utvalg nedsatt av Regjeringen, bl.a. om organiseringen av politiet i Norge og om farlige kriminelle. Han har i årevis vaert aktiv innen Nordisk Samarbeidsråd for Kriminologi. I et komparativt perspektiv (jfr Gulag-boken) fremstår Skandinavia som relativt human mht fengslingspolitikk, og selv om dette selvsagt har mange årsaker, så bør man ikke undervurdere innflytelsen fra de Skandinaviske kriminologer.

Nils Christies forfatterskap er preget av en evne til å finne samfunnsmessige svært relevante problemstillinger, nitid empirisk gransking (Nils Christie er svart nøye med alt datamateriale), av en glitrende god penn, evne og vilje til formidling (som gjenspeiles i hans fengende boktitler), utifra et ønske om å nå ut til - og påvirke - offentligheten.

Nils Christie har i mange år vart instituttleder ved Institutt for kriminologi og strafferett, rettssosiologi UiO. Han har hatt forskningsopphold ved flere utenlandske universitet (Berkeley, Jerusalem og Oxford) og han er svaert mye 
brukt som foredragsholder, både i inn- og utland. Han har væert medlem av The National Criminal Justice Commission in Washington. Han er medlem av Vitenskapsakademiet i Oslo og i Lund, og er æeresdoktor ved flere utenlandske universitet (København, Stockholm og Sheffield) (Kalleberg 2000). Han fikk velfortjent Fritt Ords pris i 2001.

Sammen med Torstein Eckhoff redigerte Nils Christie en samling av Vilhelm Auberts skrifter utgitt til Auberts 60 års dag. I forordet karakteriserer de Aubert med ord som jeg gjerne vil bruke om Nils Christie også:

"Han er en villende sosiolog. Han vil vite. Og han vil handle. Det er noe gammelmodig over Vilhelm Aubert (les: Nils Christie). (---) Han tar ansvar. Han har ... fått det for seg at tingene ikke kan få gå sin skjeve gang. I all sin radikalisme er han en samfunnsstøtte. $A v$ den typen som endrer for å bevare. Samtidig ivaretar han en gammeldags tradisjon om forsvar for svakhet.» (Ufred, "Til en venn og larer», av T. Eckhof og Nils Christie.)

På høy tid at norsk sosiologforening hedrer deg - gratulerer med hedersprisen 2005 !

\section{Referanser}

Nils Christie. (1952.) Fangevoktere $i$ konsentrasjonsleire. En sosiologisk undersøkelse av norske fangevoktere i «serberleirene» i Nord-Norge i 1942-43. Magisteravhandling. Universitetet i Oslo. Instituttet for sosiologi.

Nils Christie. (1972.) Fangevoktere $i$ konsentrasjonsleire. En sosiologisk undersøkelse av norske fangevoktere i «serberleirene» i Nord-Norge i 1942-43. Oslo: Pax Forlag AS.

Nils Christie. (1960.) Unge norske lovovertredere. Oslo: Universitetsforlaget.

Nils Christie. (1960.) Tvangsarbeid og alkoholbruk. Oslo: Universitetsforlaget.

Nils Christie. (1968.) «Editor's preface», Scandinavian Studies of Criminology, 1968, vol. 2, temanummer om "Aspects of Social Control in Welfare States".

Nils Christie. (1971.) Hvis skolen ikke fantes. Oslo: Universitetsforlaget.

Nils Christie. (1982.) Hvor tett et samfunn. Oslo: Universitetsforlaget.

Nils Christie. (1982.) Pinens begrensing. Oslo: Universitetsforlaget og Chr. Ejlers' forlag.
Nils Christie. (1989) Bortenfor anstalt og ensomhet. Om landsbyer for usedvanlige mennesker. Oslo: Universitetsforlaget.

Nils Christie. (1992.) "På leting etter det alminnelige», Tidsskrift for samfunnsforskning, vol. 33: 365-369.

Nils Christie. (1993.) Kriminalitetskontroll som industri. Mot GULAG, vestlig type? Oslo: Universitetsforlaget.

Nils Christie. (1997.) "Sosial kontroll», i Kriminologi, red. av Finstad og Heigård, Oslo: Pax forlag A/S.

Nils Christie og Kettil Brun. (1985.) Den gode fiende. Narkotikapolitikk i Norden. Oslo: Universitetsforlaget.

Nils Christie og Torstein Eckhof . (1982.) «Til en venn og lærer", i Ufred, av Vilhelm Aubert. Oslo: Pax forlag A.S.

Nils Christie, Johs.Andenæes og Sigurd Skirbekk. (1965.) "A Study of Self-reported Crime», Scandinavian Studies in Criminology, pp. 86-116.

Ragnvald Kalleberg. (2000.) Nils Christie. Norsk biografisk leksikon, bind 2, 2000.

Willy Pedersen. (1992.) «Ungdomskriminalitet: Nyanser I grått?", Tidsskrift for samfunnsforskning, vol. 33: 353-364. 